Bull. Chem. Soc. Ethiop. 2019, 33(3), 425-436.

ISSN 1011-3924

(c) 2019 Chemical Society of Ethiopia and The Authors

Printed in Ethiopia

DOI: https://dx.doi.org/10.4314/bcse.v33i3.4

\title{
BORASSUS AETHIOPUM SHELL-BASED ACTIVATED CARBON AS EFFICIENT ADSORBENT FOR CARBOFURAN
}

\author{
Zaharaddeen N. Garba ${ }^{1 *}$, Abdulkadir Tanimu ${ }^{1}$ and Zakariyya U. Zango ${ }^{2}$ \\ ${ }^{1}$ Department of Chemistry, Ahmadu Bello University, P.M.B. 1044, Zaria, Nigeria \\ ${ }^{2}$ Department of Chemistry, College of Natural and Applied Science Al-Qalam University, \\ Katsina, Nigeria
}

(Received October 3, 2018; Revised July 8, 2019; Accepted August 20, 2019)

\begin{abstract}
Carbofuran, a pesticide applied in farmlands, often gets washed away into water bodies due to heavy rainfall and renders the water toxic. In this study, Borassus aethiopum shells-based activated carbon (BASAC) was prepared using $\mathrm{CO}_{2}$ and $\mathrm{KOH}$ as physical and chemical activating agents, respectively, which was employed as an adsorbent for the removal of carbofuran from an aqueous medium. The adsorbent was produced using the impregnation ratio of 3.28 , activation temperature of $800{ }^{\circ} \mathrm{C}$ and activation time of 90 min. Textural properties and available functional groups in the adsorbent were determined using $\mathrm{N}_{2}$ adsorption-desorption isotherm and Fourier transform infrared spectroscopy, respectively. The removal efficiency was performed after optimizing the adsorption parameters and kinetics of the adsorption process was examined using a batch system. The surface area, average pore diameter and adsorption capacity of the BAS-AC were obtained as $632 \mathrm{~m}^{2} / \mathrm{g}, 2.97$ $\mathrm{nm}$ and $160 \mathrm{mg} / \mathrm{g}$, respectively. Equilibrium adsorption isotherms were fitted better by the Langmuir model than the Temkin and Freundlich models. The adsorption kinetics follow the pseudo-second-order model and the adsorbent diffusion mechanism was further studied using the intraparticle diffusion model.
\end{abstract}

KEY WORDS: Borassus aethiopum, Carbofuran, Activated carbon, Adsorption isotherm, Adsorption kinetics

\section{INTRODUCTION}

The continuous application of chemical pesticides on agricultural crops enhances the availability of good crops round the year. However, the excess use of these pesticides result in numerous environmental challenges through poisoning of water, both surface and ground, with their toxic effects thus bringing numerous difficulty to the non-target beings including human and aquatic organisms [1]. The presence of pesticides in the environment and in reasonable quantity has recently become increasingly alarming since their discovery in various water sources as well as soil have severally been reported [2]. Carbofuran, a derivative of carbamate pesticides, also named 2,3-dihydro-2,2-dimethylbenzofuran-7-yl methyl carbamate, is often used as pesticides on potatoes, fruits, vegetables, soybeans and rice [3]. The intense use of carbofuran for this process has become an environmental problem resulting from its toxic and carcinogenic properties [3]. Hence, it is very important to get rid of this toxic chemical from the contaminated water sources. The use of activated carbon (AC) by a process of adsorption is a frequent and effectual way of eliminating the toxic and dangerous pollutant from wastewater [4-6]. Recently, the use of less expensive and locally derived agricultural waste materials as AC precursor, and therefore, substituting the commercial $\mathrm{AC}$ have been reported [4, 7-13]. The commercial AC is known to be expensive and often difficult to regenerate [14-18].

In our previous work, we have demonstrated the potential of Borassus aethiopum (BAS) shell as an excellent source for generating AC [19]. However, there is rarely a research carried out for the removal of carbofuran by AC derived from the shells of BAS. Most of the reported studies concentrated more on the obliteration of dyes from wastewater. Therefore, the target of this work is to probe the effectiveness of BAS-AC in the adsorption of carbofuran from aqueous solution, determine the suitable isotherm and kinetic model parameters as well as adsorption mechanism.

*Corresponding author. dinigetso2000@gmail.com

This work is licensed under the Creative Commons Attribution 4.0 International License 


\section{Materials}

\section{EXPERIMENTAL}

Potassium hydroxide $(\mathrm{KOH})$ and carbofuran were ordered from Sigma-Aldrich. The chemical structure of carbofuran is demonstrated in Figure 1a. Deionized water was generated in-house. BAS shells were sourced from Chikun, Kaduna South, Kaduna State, Nigeria.

Preparation of $B A S-A C$

The BAS-AC was prepared following our previously reported methodology with slight modifications [19]. The modifications were done by impregnating BAS with $\mathrm{KOH}$ as chemical activating agent. The preparation was done at optimized activation temperature, time and impregnation ratio of $800^{\circ} \mathrm{C}, 90 \mathrm{~min}$ and 3.28 , respectively.

\section{Characterization of the $B A S-A C$}

The $\mathrm{N}_{2}$ adsorption-desorption isotherm performed using micromeritics ASAP 2020 was used to ascertain the textural properties of the developed BAS-AC. Fourier transform infrared (FT-IR) spectroscopy (Perkin Elmer, Model 4500 FT-IR, USA) was used to identify the functional groups available in the AC.

Batch equilibrium and kinetic studies

About $150 \mathrm{~mL}$ of aqueous solution of carbofuran at different initial concentration $(30,60,100$ and $200 \mathrm{mg} / \mathrm{L}$ ) were prepared in $250 \mathrm{~mL}$ flask. A $0.15 \mathrm{~g}$ of BAS-AC was added to each flask and the mixture was stirred for $18 \mathrm{~h}$ at $30{ }^{\circ} \mathrm{C}$ and $140 \mathrm{rpm}$ speed. The change in carbofuran concentration was monitored using Helios $\gamma$ UV-VIS spectrophotometer at wavelength of 615 $\mathrm{nm}$. The percentage removal of carbofuran at equilibrium $(\% \mathrm{R})$ was calculated using equation 1.

Carbofuran removal $(\% \mathrm{R})=\frac{\mathrm{C}_{\mathrm{o}}-\mathrm{C}_{\mathrm{e}}}{C_{o}} \times 100$

where $\mathrm{C}_{\mathrm{o}}$ and $\mathrm{C}_{\mathrm{e}}$ represent the initial and equilibrium concentrations $(\mathrm{mg} / \mathrm{L})$ of carbofuran, respectively. The amount per unit mass of adsorbent, $q_{e}(\mathrm{mg} / \mathrm{g})$ of carbofuran adsorbed at equilibrium, was calculated using the equation:

$q_{e}=\frac{\left(C_{o}-C_{e}\right) V}{W}$

where V $(\mathrm{L})$ is the volume of the solution and $\mathrm{W}(\mathrm{g})$ is the mass of the adsorbent used, and the amount of carbofuran adsorbed at time $\mathrm{t}, q_{t}(\mathrm{mg} / \mathrm{g})$ was calculated using equation 3 :

$q_{t}=\frac{\left(C_{o}-C_{t}\right) V}{W}$

where $C_{t}(\mathrm{mg} / \mathrm{L})$ represent the concentration of carbofuran at time t. The effect of initial $\mathrm{pH}(2-$ 12) on the adsorption of the carbofuran by BAS-AC was studied by adjusting the solution $\mathrm{pH}$ with $0.1 \mathrm{M} \mathrm{HCl}$ and $0.1 \mathrm{M} \mathrm{KOH}$ solutions. The initial concentration of carbofuran was $30 \mathrm{mg} / \mathrm{L}$ with BAS-AC dosage of $0.15 \mathrm{~g}$ at a temperature of $30{ }^{\circ} \mathrm{C}$ for $12 \mathrm{~h}$. The $\% \mathrm{R}$ was calculated using equation (1).

\section{Characterization of $B A S-A C$}

\section{RESULTS AND DISCUSSION}

Porosity and surface area are among the major general properties that define a good adsorbent. The BET surface area, total pore volume and average pore diameter of the BAS-AC were obtained to be $632 \mathrm{~m}^{2} / \mathrm{g}, 0.39 \mathrm{~cm}^{3} / \mathrm{g}$ and $2.97 \mathrm{~nm}$ respectively. The obtained BAS-AC surface area compared very well with other adsorbents such as mesoporous activated carbon from coconut frond $\left(484 \mathrm{~m}^{2} / \mathrm{g}\right)$ [1], rapeseed stalks activated carbon $\left(490 \mathrm{~m}^{2} / \mathrm{g}\right)$, soya stalks activated 
carbon $\left(570 \mathrm{~m}^{2} / \mathrm{g}\right)$, olive kernels activated carbon $\left(600 \mathrm{~m}^{2} / \mathrm{g}\right)$ and corn cobs activated carbon $\left(630 \mathrm{~m}^{2} / \mathrm{g}\right)$ [20] employed in the adsorption of other pesticides, implying that our synthesis strategy for BAS-AC was very successful. The presence of active functionality on the BAS-AC surface was confirmed by FT-IR spectroscopy. The spectra of BAS-AC before and after carbofuran adsorption are shown in Figure 1b.

(a)

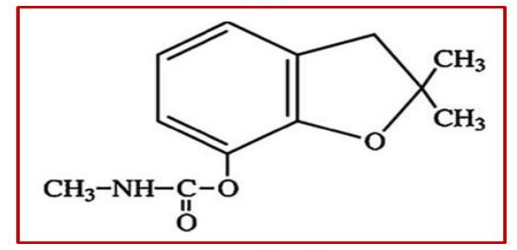

(b)

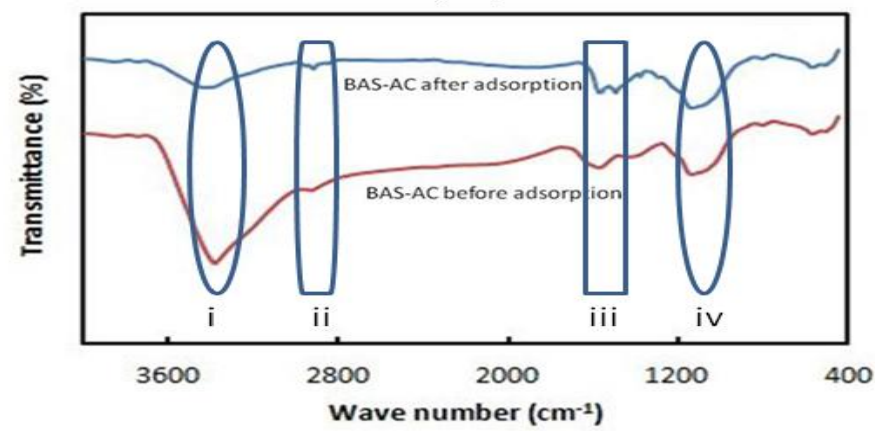

Figure 1. (a) Chemical structure of carbofuran and (b) FTIR spectra of BAS-AC before and after carbofuran adsorption.

The possible interaction of active functional groups to enhance pesticide ions uptake was revealed by the shift of the peaks to different bands, reduced peak intensity or their disappearance after adsorption. Presence of $\mathrm{O}-\mathrm{H}$ or $\mathrm{N}-\mathrm{H}$ functional groups, were obtained between the broad bands of $3500-3200 \mathrm{~cm}^{-1}$ (i) those from $3000-2800 \mathrm{~cm}^{-1}$, (ii) are assigned to saturated C-H, while bands revealed at $1500-1600 \mathrm{~cm}^{-1}$ and $1500-1400 \mathrm{~cm}^{-1}$ and (iii) were for $\mathrm{C} \equiv \mathrm{N}$ and $\mathrm{C}-\mathrm{C}$ stretching, respectively $[21,22]$. In addition to this, the bands existing between $1260-1050 \mathrm{~cm}^{-1}$ (iv) were assigned to $\mathrm{C}-\mathrm{O}$ stretching in phenols ,carboxyl acids, esters and alcohols [23].

\section{Effect of contact time and initial carbofuran concentration}

The influence of contact time on the exclusion of carbofuran by BAS-AC for four distinct initial concentrations at $30{ }^{\circ} \mathrm{C}$ is illustrated in Figure 2a. It was characterised by a quick increase at the start of the adsorption for all tested concentrations, then later followed by a much slower uptake till equilibration. The adsorption continued at a slower pace until unnoticeable adsorption was observed, that is the point where dynamic equilibrium exists: where the rate of adsorption onto the surface of the adsorbent is equivalent to the amount desorbed by the same surface. The dynamic equilibrium stage acts as the determinant time to examine the degree of adsorption by an adsorbent [24].

It is observed that an increase in the pesticide initial concentrations results in sudden rise in adsorption capacity from 10.9 to $115 \mathrm{mg} / \mathrm{g}$. As shown in Figure 2a, the rate of carbofuran 
adsorption was very high in the first 24 min, and then decreased gradually until equilibrium was attained within $8 \mathrm{~h}$. By extending the contact time from $8 \mathrm{~h}$ to $18 \mathrm{~h}$, no significant increase in the adsorption was noticed, rather the desorption of carbofuran molecules into the solution was observed after $18 \mathrm{~h}$ contact time. It was further observed that samples of higher carbofuran concentrations takes longer contact time to reach equilibration. An approximate of $5 \mathrm{~h}$ contact time was used by carbofuran solutions with initial concentrations of 30 and $60 \mathrm{mg} / \mathrm{L}$ to reach equilibrium, and $8 \mathrm{~h}$ contact time for solution of higher initial concentrations. This means higher carbofuran concentration will experience fast adsorption phenomenon by BAS-AC $[1,19,25$, 26].

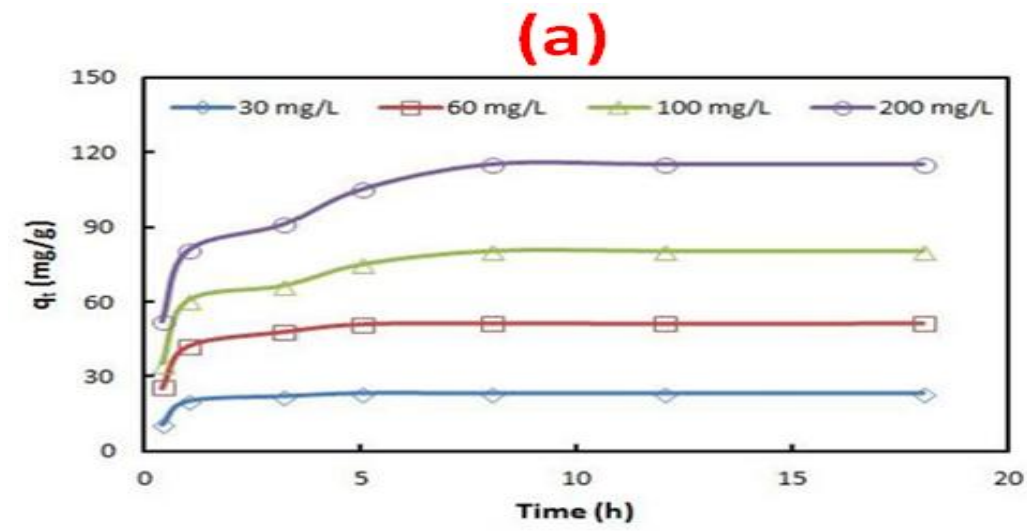

(b)

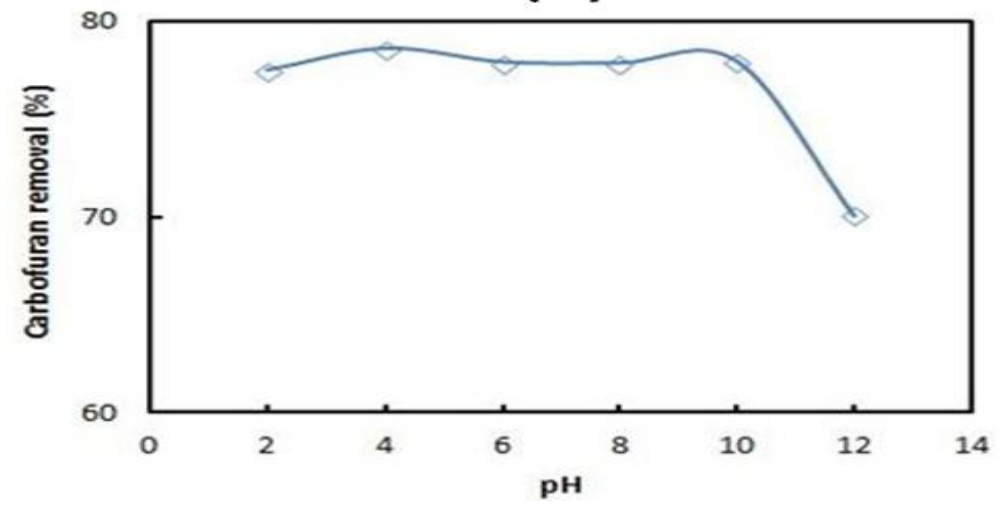

Figure 2. (a)Effect of contact time and initial concentration and (b) solution $\mathrm{pH}$ on the removal of carbofuran $(\%)$ onto BAS-AC at $303 \mathrm{~K}$.

\section{Effect of pH on carbofuran adsorption}

The solution $\mathrm{pH}$ was varied from 2-12 to study its effect on the carbofuran adsorption onto BAS-AC. The result obtained is shown in Figure $2 b$. As observed in Figure $2 b$, increase in solution $\mathrm{pH}$ does not cause any major difference in the carbofuran adsorbed amount which was attributed to the non-ionic nature of the adsorbate $\left(\mathrm{pK}_{\mathrm{a}}=11.90\right)$ [27]. Other researchers reported difficulty in dissolving carbofuran in solution because of it having low acidic or basic functionalities [1] confirming the interaction between BAS-AC surface and carbofuran to be non-electrostatic. 


\section{Effect of solution temperature on carbofuran adsorption}

The influence of solution temperatures $\left(30,40\right.$ and $\left.50{ }^{\circ} \mathrm{C}\right)$ on the carbofuran adsorption onto the prepared BAS-AC was investigated with other parameters kept constant. The carbofuran maximum adsorption capacities were affected by the solution temperatures as can be seen to be decreasing slightly as the solution temperature was raised from 30 to $50{ }^{\circ} \mathrm{C}$, indicating that the adsorption process was exothermic in nature. The physical bonding between the adsorbent active sites and organic compounds (including pesticides) was justified to be weakened with an increase in temperature. Moreover, the interaction forces between the solvent and solute becomes greater which was related to the observed increase in the solubility of carbofuran, hence making it more challenging for the solute to be adsorbed [28].

\section{Adsorption isotherm}

Three popular isotherms of adsorption (Langmuir, Freundlich and Temkin) were applied in this work to analyse the equilibrium data generated. They are mathematically described as: [29-31].

$\frac{C_{e}}{q_{e}}=\frac{1}{K_{L} \cdot Q_{a}^{0}}+\frac{C_{e}}{Q_{a}^{0}}$

$\log \mathrm{q}_{\mathrm{e}}=\log \mathrm{K}_{\mathrm{F}}+\frac{1}{\mathrm{n}} \log \mathrm{C}_{\mathrm{e}}$

$\mathrm{q}_{\mathrm{e}}=\frac{\mathrm{RT}}{\mathrm{b}} \operatorname{In} \mathrm{A}+\frac{\mathrm{RT}}{\mathrm{b}} \operatorname{InC}_{\mathrm{e}}$

where $C_{e}(\mathrm{mg} / \mathrm{L})$ is the equilibrium concentration of the adsorbates, $\mathrm{q}_{\mathrm{e}}$ stand for the adsorbates amount adsorbed per unit adsorbent weight while $Q_{a}^{0}(\mathrm{mg} / \mathrm{g})$ and $K_{L}(\mathrm{~L} / \mathrm{mg})$ are Langmuir constants related to maximum adsorption capacity and rate of adsorption, respectively, $\mathrm{K}_{\mathrm{F}}$ $\left(\mathrm{mg}^{1-\mathrm{n}} / \mathrm{g} \mathrm{L}^{\mathrm{n}}\right)$ is the adsorption capacity when the adsorbate equilibrium concentration equal to $1.00 \mathrm{mg} / \mathrm{L}$ [32] with $\mathrm{n}$ related to adsorption intensity [33]. In general, $\mathrm{n}>1$ suggests that adsorbate is favourably adsorbed on the adsorbent [34]. The higher the $n$ value the stronger the adsorption intensity. $\mathrm{A}(\mathrm{L} / \mathrm{g})$ and $\frac{\mathrm{RT}}{\mathrm{b}}=\mathrm{B}(\mathrm{J} / \mathrm{mol})$ are Temkin constants, which are related to heat of sorption and maximum binding energy, respectively [35], $\mathrm{R}$ is the gas constant $(8.31$ $\mathrm{J} / \mathrm{mol} / \mathrm{K}$ ) and $\mathrm{T}(\mathrm{K})$ is the absolute temperature. Dimensionless separation factor, $\mathrm{R}_{\mathrm{L}}$ is essential characteristic of the Langmuir equation defined as [36]:

$R_{L}=\frac{1}{1+K_{L} C_{o}}$

where $C_{o}$ is the highest initial solute concentration. $R_{L}$ values indicate whether the adsorption is unfavourable $\left(R_{L}>1\right)$, linear $\left(R_{L}=1\right)$, favourable $\left(0<R_{L}<1\right)$, or irreversible $\left(R_{L}=0\right)$. Correlation coefficient $\left(\mathrm{R}^{2}\right)$ alone was reported not to be reliable in determining the best model for analyzing the experimental data, for that we integrated normalized standard deviation $(\Delta q)$ so as to be more certain in choosing the best adsorption model. $\Delta \mathrm{q}$ was calculated using the below equation

$\Delta q(\%)=100 \sqrt{\frac{\sum\left(\frac{q_{\exp }-q_{c a l}}{q_{\exp }}\right)^{2}}{N-1}}$

where experiment and calculated carbofuran adsorption capacities were represented by $q_{\text {exp }}$ and $q_{\text {cal }}$, respectively. $\mathrm{N}$ is the number of experiments carried out. The isotherm with lower $\Delta \mathrm{q}$ value is the best to describe the equilibrium data as confirmed by the literature [37]. The values of $\mathrm{R}^{2}$ and $\Delta \mathrm{q}(\%)$ with respect to the studied isotherm models were summarized in Table 1. Based on the high $\mathrm{R}^{2}$ values as well as lower percentage $\Delta \mathrm{q}$ values, it can be seen clearly that Langmuir (Figure 3a) fits the data better than both Temkin and Freundlich isotherms connoting 
the adsorption process to be homogeneous on specific monolayer [19]. Still as observed from Table 1, better adsorption conditions for carbofuran in aqueous solution were further signified based on the $n$ values from the Freundlich plot (Figure 3b) which were found to be greater than 1 at all the examined temperatures. The values of A and B were also obtained from Temkin plot (Figure 3c).

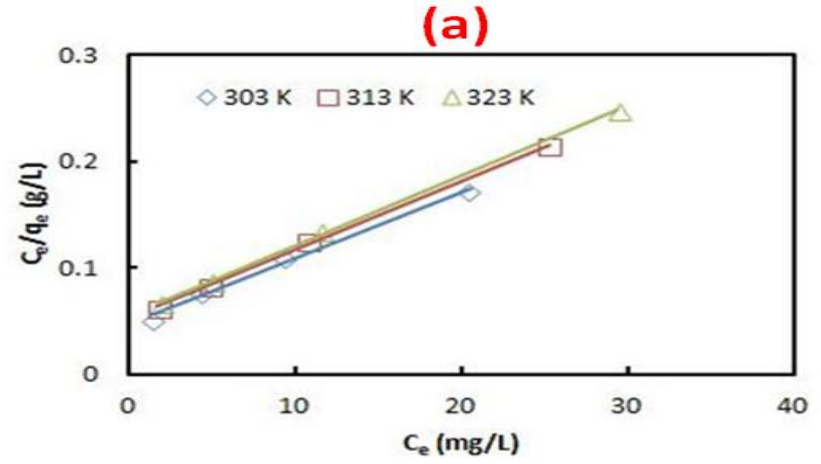

(b)

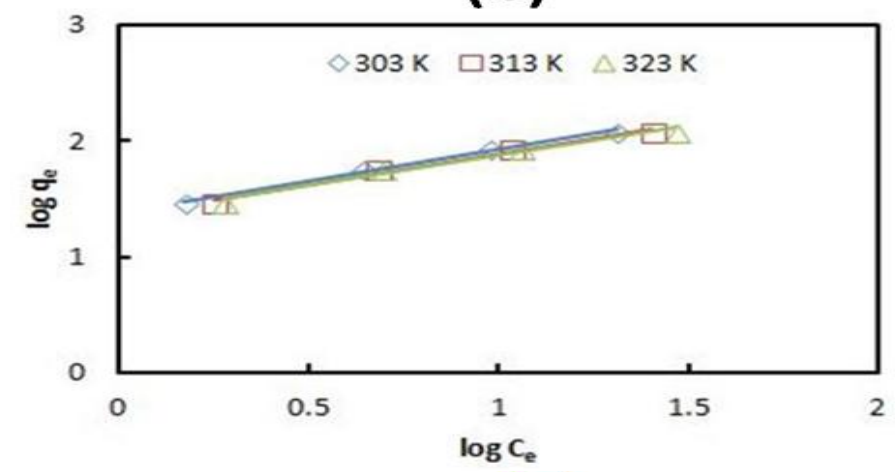

(c)

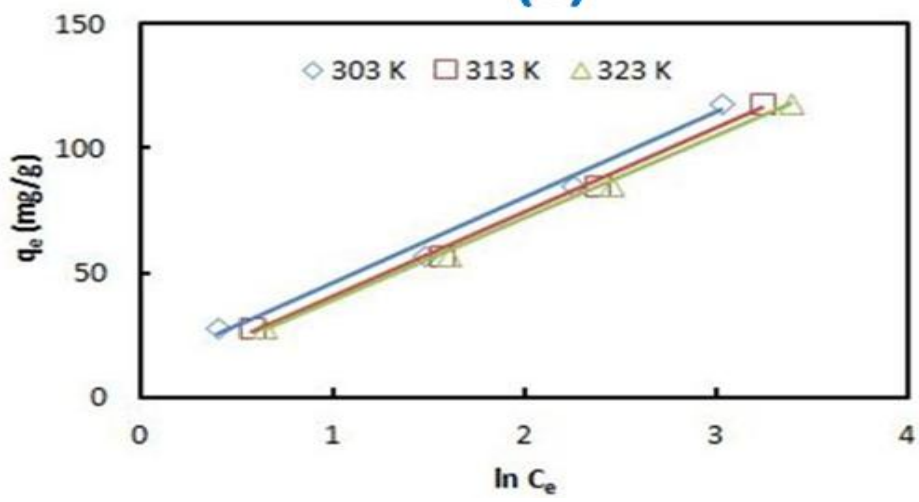

Figure 3. (a) Langmuir isotherms, (b) Freundlich isotherms and (c) Temkin isotherms of carbofuran adsorption onto BAS-AC at different temperatures. 
Table 1. Langmuir, Freundlich and Temkin isotherm model parameters for the adsorption of carbofuran onto BAS-AC at different temperatures.

\begin{tabular}{|l|l|l|l|l|}
\hline Isotherms & Parameters & \multicolumn{4}{l|}{ Temperature $(\mathrm{K})$} & \multicolumn{2}{l|}{} \\
\hline & & $30{ }^{\circ} \mathrm{C}$ & $40{ }^{\circ} \mathrm{C}$ & $50{ }^{\circ} \mathrm{C}$ \\
\hline Langmuir & $Q_{a}^{0}(\mathrm{mg} / \mathrm{g})$ & 160 & 156 & 152 \\
\hline & $\mathrm{K}_{\mathrm{L}}(\mathrm{L} / \mathrm{mg})$ & 0.314 & 0.122 & 0.121 \\
\hline & $\mathrm{R}^{2}$ & 0.9949 & 0.9985 & 0.9992 \\
\hline & $\Delta \mathrm{q}(\%)$ & 2.86 & 2.97 & 3.07 \\
\hline & $\mathrm{K}_{\mathrm{F}}\left(\mathrm{mg}^{1-\mathrm{n}} / \mathrm{g} \mathrm{L}^{\mathrm{n}}\right)$ & 3.49 & 3.41 & 3.27 \\
\hline Freundlich & $\mathrm{n}$ & 1.39 & 1.36 & 1.36 \\
\hline & $\mathrm{R}^{2}$ & 0.9903 & 0.9797 & 0.9719 \\
\hline & $\Delta \mathrm{q}(\%)$ & 12.3 & 15.9 & 19.4 \\
\hline & $\mathrm{A}(\mathrm{L} / \mathrm{g})$ & 1.41 & 1.23 & 1.22 \\
\hline Temkin & $\mathrm{B}(\mathrm{J} / \mathrm{mol})$ & 34.3 & 33.9 & 32.9 \\
\hline & $\mathrm{R}^{2}$ & 0.9883 & 0.9959 & 0.9985 \\
\hline & $\Delta \mathrm{q}(\%)$ & 5.87 & 6.32 & 6.02 \\
\hline
\end{tabular}

Table 2. Comparison of Langmuir adsorption capacities for the adsorption of carbofuran on various ACs.

\begin{tabular}{|l|l|l|l|}
\hline Adsorbent & Temperature $\left({ }^{\circ} \mathrm{C}\right)$ & $Q_{a}^{0}(\mathrm{mg} / \mathrm{g})$ & Reference \\
\hline BAS-AC & 30 & 160 & This work \\
\hline BAS-AC & 40 & 156 & This work \\
\hline BAS-AC & 50 & 152 & This work \\
\hline Coconut frond AC & 30 & 198 & {$[1]$} \\
\hline Coconut frond AC & 40 & 193 & {$[1]$} \\
\hline Coconut frond AC & 50 & 205 & {$[1]$} \\
\hline Date seed AC & 30 & 137 & {$[38]$} \\
\hline Chestnut shells & 30 & 2.39 & {$[39]$} \\
\hline Banana stalk AC & 30 & 156 & {$[40]$} \\
\hline Commercial GAC & 30 & 96.2 & {$[41]$} \\
\hline
\end{tabular}

The $Q_{a}^{0}$ values obtained at 30,40 and $50{ }^{\circ} \mathrm{C}$ were 160,156 and $152 \mathrm{mg} / \mathrm{g}$, respectively, confirming an excellent monolayer adsorption of the carbofuran on the BAS-AC surface which compared very well with other adsorbents (Table 2).

\section{Adsorption kinetic studies}

For better understanding of the adsorption process nature, the adsorption kinetics data generated were fitted by the pseudo-first-order, pseudo-second-order and intra-particle diffusion kinetic model with their respective equations expressed as:

$\log \left(\mathrm{q}_{\mathrm{e}}-\mathrm{q}_{\mathrm{t}}\right)=\log \mathrm{q}_{\mathrm{e}}-\frac{\mathrm{k}_{1}}{2.303} \mathrm{t}$

$\frac{\mathrm{t}}{\mathrm{q}_{\mathrm{t}}}=\frac{1}{\mathrm{k}_{2} \mathrm{q}_{\mathrm{e}}^{2}}+\frac{1}{\mathrm{q}_{\mathrm{e}}} \mathrm{t}$

$\mathrm{q}_{\mathrm{t}}=\mathrm{k}_{\mathrm{ip}} \mathrm{t}^{0.5}+\mathrm{C}$

where $\mathrm{q}_{\mathrm{e}}$ and $\mathrm{q}_{\mathrm{t}}$ are the amounts of carbofuran $(\mathrm{mg} / \mathrm{g})$ adsorbed at equilibrium and at time $\mathrm{t}(\mathrm{h})$, respectively while $\mathrm{k}_{1}(1 / \mathrm{h})$ and $\mathrm{k}_{2}(\mathrm{~g} / \mathrm{mg} \mathrm{h})$ are the adsorption rate constants of pseudo first and second-order adsorption respectively, $\mathrm{k}_{\mathrm{ip}}$ is the rate constant of the intra-particle diffusion equation and $\mathrm{C}$ gives information about the boundary layer thickness: larger value of $\mathrm{C}$ is associated with the boundary layer diffusion effect.

Figure 4 (a-c) shows the fitting curves for the models from where the kinetic parameters presented in Table 3 were evaluated. The $\mathrm{R}^{2}$ values for pseudo-first-order model (Figure $4 \mathrm{a}$ ) were smaller when compared with the values obtained from pseudo-second-order model (Figure 
4b) confirming pseudo-second-order model to be the best fit for the carbofuran adsorption onto BAS-AC adsorbent. Additionally, the linear lines of the intraparticle plots (Figure 4c) have an intercept not equal to zero signifying that other rate controlling steps are involved in the process in addition to the intraparticle diffusion.

Table 3. Kinetic parameters at different initial concentrations for adsorption of carbofuran onto BAS-AC.

\begin{tabular}{|l|l|l|l|l|l|l|l|}
\hline $\begin{array}{l}\mathrm{C}_{\mathrm{o}} \\
(\mathrm{mg} / \mathrm{L})\end{array}$ & $\begin{array}{l}\text { q } \\
(\mathrm{mg} / \mathrm{g})\end{array}$ & \multicolumn{2}{l|}{ Pseudo-first-order kinetic model } & \multicolumn{2}{l|}{ Pseudo-second-order kinetic model } \\
\hline & & $\mathrm{k}_{1}(1 / \mathrm{h})$ & $\mathrm{q}_{\mathrm{e} \text { cal }}(\mathrm{mg} / \mathrm{g})$ & $\mathrm{R}^{2}$ & $\mathrm{k}_{2}(\mathrm{~g} / \mathrm{mg} \mathrm{h})$ & $\mathrm{q}_{\mathrm{e} \text { cal }}(\mathrm{mg} / \mathrm{g})$ & $\mathrm{R}^{2}$ \\
\hline 30 & 28.8 & 0.043 & 9.81 & 0.4159 & 0.178 & 23.6 & 0.9996 \\
\hline 60 & 57.4 & 0.072 & 15.4 & 0.5179 & 0.073 & 52.4 & 0.9997 \\
\hline 100 & 86.0 & 0.116 & 28.0 & 0.7235 & 0.023 & 83.3 & 0.9992 \\
\hline 200 & 119 & 0.178 & 39.8 & 0.7776 & 0.014 & 120 & 0.9987 \\
\hline
\end{tabular}

The suitability of pseudo-second-order model in describing the kinetic adsorption data implies that the adsorption rate plays a key role more than the carbofuran concentration in making the adsorption sites more available in the solution [1]. This is consistent with what other researchers reported for the adsorption of the same adsorbate onto coconut frond as well as date seed AC $[1,38]$.

\section{Intraparticle diffusion study}

The pseudo-first-order and pseudo-second-order kinetic models could not ascertain the sorption mechanism[42] the kinetic results were further examined for the diffusion mechanism by utilizing the intraparticle diffusion model (equation 11). Based on the non linearity of the intraparticle plots over several concentrations examined as can be observed from the origin as well as low $\mathrm{R}^{2}$ values for intraparticle diffusion model as presented in Table 4, it can be assumed that several processes controls the adsorption process. $\mathrm{k}_{\mathrm{pi}}, \mathrm{C}_{\mathrm{i}}$ values where inserted alongside $\mathrm{R}^{2}$ values in Table 4. The increase in the thickness of the boundary layer as well as greater driving force were the reason for the improvement in $\mathrm{k}_{\mathrm{p} 2}, \mathrm{C}_{2}$ and $\mathrm{C}_{3}$ with an upsurge in the initial carbofuran concentration [43].

Table 4. Intraparticle diffusion model parameters for the adsorption of carbofuran onto BAS-AC.

\begin{tabular}{|l|l|l|l|l|l|l|}
\hline $\mathrm{C}_{\mathrm{o}}(\mathrm{mg} / \mathrm{L})$ & $\mathrm{k}_{\mathrm{p} 2}\left(\mathrm{mg} / \mathrm{g} \mathrm{h}^{0.5}\right)$ & $\mathrm{k}_{\mathrm{p} 3}\left(\mathrm{mg} / \mathrm{g} \mathrm{h}^{0.5}\right)$ & $\mathrm{C}_{2}$ & $\mathrm{C}_{3}$ & $\left(\mathrm{R}_{2}\right)^{2}$ & $\left(\mathrm{R}_{3}\right)^{2}$ \\
\hline 30 & 6.52 & 0.0078 & 9.79 & 23.1 & 0.7322 & 0.3020 \\
\hline 60 & 14.1 & 0.0024 & 21.8 & 51.3 & 0.8106 & 0.0034 \\
\hline 100 & 21.2 & 0.0078 & 29.1 & 80.3 & 0.8161 & 0.3020 \\
\hline 200 & 29.0 & 0.0078 & 41.4 & 115 & 0.8882 & 0.3020 \\
\hline
\end{tabular}

Carbofuran adsorption thermodynamic studies

The thermodynamic parameters studied in this work were Gibb's free energy change $(\Delta G)$, enthalpy change $(\Delta \mathrm{H})$ and entropy change $(\Delta \mathrm{S})$. They were related to each other by Van't Hoff equation $[44,45]$ expressed as:

$\ln \mathrm{K}_{\mathrm{D}}=\frac{\Delta \mathrm{S}}{\mathrm{R}}-\frac{\Delta \mathrm{H}}{\mathrm{RT}}$

where $\mathrm{R}(8.314 \mathrm{~J} / \mathrm{mol} / \mathrm{K})$ is the universal gas constant; $\mathrm{T}(\mathrm{K})$ is the absolute temperature; $\mathrm{K}_{\mathrm{D}}=\frac{\mathrm{q}_{\mathrm{e}}}{\mathrm{C}_{\mathrm{e}}}$ is the distribution coefficient; $\mathrm{q}_{\mathrm{e}}(\mathrm{mg} / \mathrm{g})$ is the amount of adsorbate adsorbed on the sorbent per unit mass. $\Delta \mathrm{G}$ was evaluated from the relation below:

$\Delta \mathrm{G}=-\mathrm{RT} \ln \mathrm{K}_{\mathrm{D}}$ 


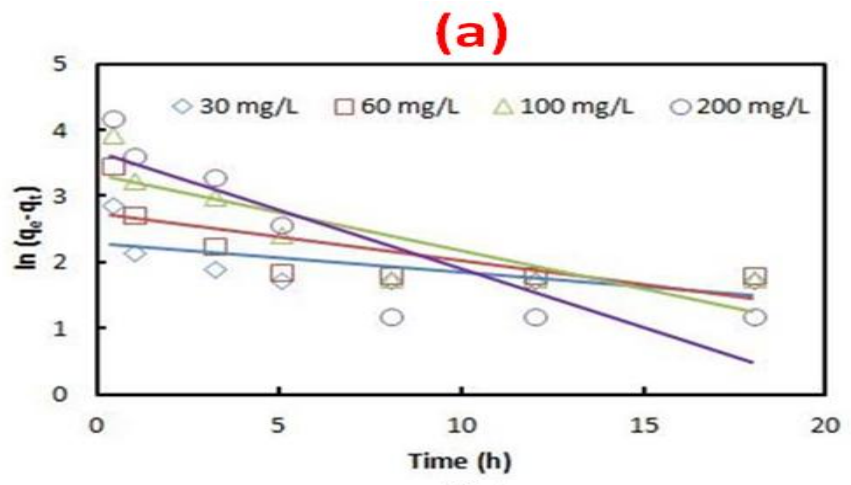

(b)
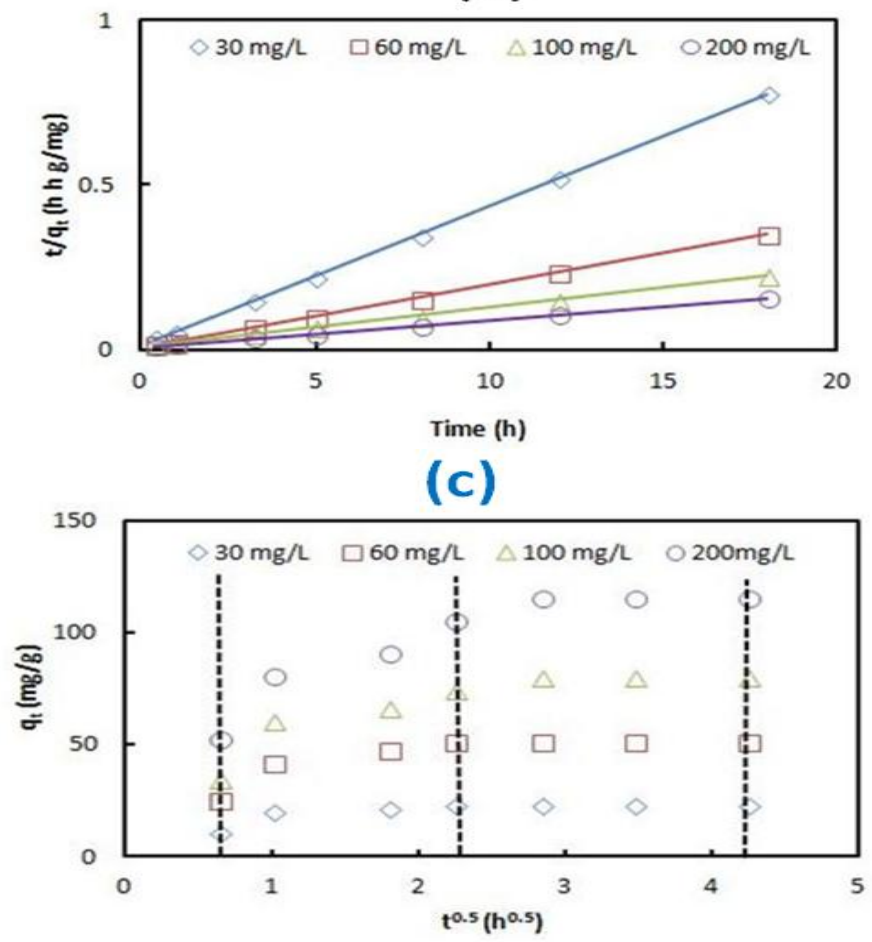

Figure 4. (a) Pseudo first order, (b) pseudo second order and (c) intraparticle diffusion kinetic plots for carbofuran adsorption onto BAS-AC at $303 \mathrm{~K}$.

Table 5. Thermodynamic parameters for the adsorption of carbofuran onto BAS-AC.

\begin{tabular}{|l|l|l|l|l|}
\hline$\Delta \mathrm{H}(\mathrm{kJ} / \mathrm{mol})$ & $\Delta \mathrm{S}(\mathrm{J} / \mathrm{mol} \mathrm{K})$ & $\Delta \mathrm{G}(\mathrm{kJ} / \mathrm{mol})$ & $50{ }^{\circ} \mathrm{C}$ \\
\hline & & $30{ }^{\circ} \mathrm{C}$ & $40{ }^{\circ} \mathrm{C}$ & -5.39 \\
\hline-0.084 & 44.1 & -5.51 & -5.40 & \\
\hline
\end{tabular}

Bull. Chem. Soc. Ethiop. 2019, 33(3) 
Negative and positive values were obtained for both $\Delta \mathrm{H}(-0.084)$ and $\Delta \mathrm{S}(44.1)$, respectively (Table 5) further implying that the carbofuran adsorption process was exothermic with random characteristics. Furthermore, the $\Delta \mathrm{G}$ values for physical adsorption lies between -20 to $0 \mathrm{~kJ} / \mathrm{mol}$ which is smaller than that of chemical adsorption ranged from -80 to $-400 \mathrm{~kJ} / \mathrm{mol}$ [46]. From the values obtained at both temperatures, it can be inferred that the nature of adsorption here is physisorption

\section{CONCLUSION}

The adsorption of carbofuran by AC obtained from Borassus aethiopum and activated by $\mathrm{KOH}$ was examined. Effect of different factors such as temperature, contact time, initial carbofuran concentration and solution $\mathrm{pH}$ were studied. Among the parameters studied, equilibrium adsorption capacity was revealed to have a linear relation with carbofuran concentration but indirect relation with solution $\mathrm{pH}$ and temperature having the maximum carbofuran adsorptive capacity of $160 \mathrm{mg} / \mathrm{g}$. The equilibrium and kinetics of the carbofuran adsorption process on the BAS-AC were best described by Langmuir and pseudo-second-order kinetic models, respectively. Results from the study affirmed that BAS-AC has a high tendency to be used as an effective and alternative adsorbent for the adsorption of pesticides.

\section{REFERENCES}

1. Njoku, V.O.; Islam, M.A.; Asif, M.; Hameed, B.H. Preparation of mesoporous activated carbon from coconut frond for the adsorption of carbofuran insecticide. J. Anal. Appl. Pyrol. 2014, 110, 172-180.

2. Ayranci, E.; Hoda, N. Adsorption kinetics and isotherms of pesticides onto activated carboncloth. Chemosphere 2005, 60, 1600-1607.

3. Chang, K.L.; Chen, C.C.; Lin, J.H.; Hsien, J.F.; Wang, Y.; Zhao, F.; Shih, Y.H.; Xing, Z.J.; Chen, S.T. Rice straw-derived activated carbons for the removal of carbofuran from an aqueous solution. New Carbon Mater. 2014, 29, 47-54.

4. Garba, Z.N.; Afidah, A.R. Evaluation of optimal activated carbon from an agricultural waste for the removal of para-chlorophenol and 2,4-dichlorophenol. Proc. Safety Environ. Protec. 2016, 102, 54-63.

5. Garba, Z.N.; Afidah, A.R.; Bello, B.Z. Optimization of preparation conditions for activated carbon from Brachystegia eurycoma seed hulls: A new precursor using central composite design. J. Environ. Chem. Eng. 2015, 3, 2892-2899.

6. Huang, R.; Liu, Q.; Huo, J.; Yang, B. Adsorption of methyl orange onto protonated crosslinked chitosan. Arab. J. Chem. 2017, 10, 24-32.

7. Ait Ahsaine, H.; Zbair, M.; Anfar, Z.; Naciri, Y.; El haouti, R.; El Alem, N.; Ezahri, M. Cationic dyes adsorption onto high surface area 'almond shell' activated carbon: Kinetics, equilibrium isotherms and surface statistical modeling. Mater. Today Chem. 2018, 8, 121132.

8. Alizadeh, N.; Shariati, S.; Besharati, N., Adsorption of crystal violet and methylene blue on azolla and fig leaves modified with magnetite iron oxide nanoparticles. Intl. J. Environ. Res. 2017, 11, 197-206.

9. Darweesh, T.M.; Ahmed, M.J. Adsorption of ciprofloxacin and norfloxacin from aqueous solution onto granular activated carbon in fixed bed column. Ecotoxicol. Environ. Safety 2017, 138, 139-145.

10. Prashanthakumar, T.K.M.; Kumar, S.K.A.; Sahoo, S.K. A quick removal of toxic phenolic compounds using porous carbon prepared from renewable biomass coconut spathe and exploration of new source for porous carbon materials. J. Environ. Chem. Eng. 2018, 6, 1434-1442. 
11. Jawad, A.H.; Ishak, M.A.M.; Farhan, A.M.; Ismail, K. Response surface methodology approach for optimization of color removal and COD reduction of methylene blue using microwave-induced $\mathrm{NaOH}$ activated carbon from biomass waste Desalin. Water Treat. 2017, 62, 208-220.

12. Rashid, R.A.; Jawad, A.H.; Ishak, M.A.M.; Kasim, N.N. KOH-activated carbon developed from biomass waste: Adsorption equilibrium, kinetic and thermodynamic studies for Methylene blue uptake. Desalin. Water Treat. 2016, 57, 27226-27236.

13. Jawad, A.H.; Sabar, S.; Ishak, M.A.M.; Wilson, L.D.; Ahmad Norrahma, S.S.; Talari, M.K.; Farhan, A.M. Microwave-assisted preparation of mesoporous-activated carbon from coconut (Cocos nucifera) leaf by $\mathrm{H}_{3} \mathrm{PO}_{4}$ activation for methylene blue adsorption. Chem. Eng. Commun. 2017, 204, 1143-1156.

14. Awwad, N.S.; El-Zahhar, A.A.; Fouda, A.M.; Ibrahim, H.A. Removal of heavy metal ions from ground and surface water samples using carbons derived from date pits. J. Environ. Chem. Eng. 2013, 1, 416-423.

15. González-Navarro, M.F.; Giraldo, L.; Moreno-Piraján, J.C. Preparation and characterization of activated carbon for hydrogen storage from waste African oil-palm by microwaveinduced LiOH basic activation. J. Anal. Appl. Pyrol. 2014, 107, 82-86.

16. Huang, L.; Zhou, Y.; Guo, X.; Chen, Z. Simultaneous removal of 2,4-dichlorophenol and $\mathrm{Pb}$ (II) from aqueous solution using organo clays: Isotherm, kinetics and mechanism. J. Ind. Eng. Chem. 2014, 22, 280-287.

17. Garba, Z.N.; Afida, A.R. Adsorption of 4-chlorophenol onto optimum activated carbon from an gricultural waste. Intl. J. Sci. Res. 2015, 4, 1931-1936.

18. Andrade, R.C.; de Almeida, C.F.; Suegama, P.H.; de Arrudaa, E.J.; Arroyo, P.A.; de Carvalho, C.T. Buriti palm stem as a potential renewable source for activated carbon production. Environ. Technol. Innov. 2015, 3, 28-34.

19. Garba, Z.N.; Afidah, A.R.; Hamza, S.A. Potential of borassus aethiopum shells as precursor for activated carbon preparation by physico-chemical activation: Optimization, equilibrium and kinetic studies. J. Environ. Chem. Eng. 2014, 2, 1423-1433.

20. Ioannidou, Q.A.; Zabaniotou, A.A.; Stavropoulos, G.G.; Islam, M.A.; Albanis, T.A. Preparation of activated carbons from agricultural residues for pesticide adsorption. Chemosphere 2010, 80, 1328-1336.

21. Fuente, E.; Menéndez, J.A.; Díez, M.A.; Suárez, D.; Montes-Morán, M.A. Infrared spectroscopy of carbon materials: A quantum chemical study of model compounds. J. Phys. Chem. B 2003, 107, 6350-6359.

22. Shi, Q.Q.; Zhang, J.; Zhang, C.L.; Li, C.; Zhang, B.; Hu, W.W.; Xu, J.T. Preparation of activated carbon from cattail and its application for dyes removal. J. Environ. Sci. 2010, 22, 91-97.

23. Hesas, R.H.; Niya, A.A.; Daud, W.M.A.W.; Sahu, J.N. Preparation of granular activated carbon from oil palm shell by microwave-induced chemical activation: Optimisation using surface response methodology. Chem. Eng. Res. Des. 2013, 91, 2447-2456.

24. Yao, Y.; Xu, F.; Chen, M.; Xu, Z.; Zhu, Z. Adsorption behavior of methylene blue on carbon nanotubes. Bioresour. Technol. 2010, 101, 3040-3046.

25. Islam, M.A.; Tan, I.A.W.; Benhouria, A.; Asif, M.; Hameed, B.H. Mesoporous and adsorptive properties of palm date seed activated carbon prepared via sequential hydrothermal carbonization and sodium hydroxide activation. Chem. Eng. J. 2015, 270, 187195.

26. Tan, I.A.W.; Ahmad, A.L.; Hameed, B.H. Adsorption isotherms, kinetics, thermodynamics and desorption studies of 2,4,6-trichlorophenol on oil palm empty fruit bunch-based activated carbon. J. Hazar. Mater. 2009, 164, 473-482.

27. Makehelwala, M.; Weerasooriya, R.; Jayaratne, L.; Dissanayake, C.B. Thermodynamics of carbofuran adsorption on pyrite. J. Chem. Thermodyn. 2012, 51, 1-7. 
28. Tan, I.A.W.; Ahmad, A.L.; Hameed, B.H. Adsorption of basic dye on high-surface-area activated carbon prepared from coconut husk: Equilibrium, kinetic and thermodynamic studies. J. Hazard. Mater. 2008, 154, 337-346.

29. Freundlich, H.M.F. Over the adsorption in solution. J. Phys. Chem. 1906, 57, 385-470.

30. Langmuir, I. The adsorption of gases on plane surfaces of glass, mica and platinum. J. Am. Chem. Soc. 1918, 40, 1361-1403.

31. Temkin, M.J.; Pyzhev, V. Recent modifications to Langmuir isotherms. Acta Physiochim. 1940, 12, 217-222.

32. Oo, C.W.; Kassim, M.J.; Pizzi, A. Characterization and performance of Rhizophora apiculata mangrove polyflavonoid tannins in the adsorption of copper(II) and lead(II). Ind. Crops Prod. 2009, 30, 152-161.

33. Wan Ngah, W.S.; Fatinathan, S.; Yosop, N.A. Isotherm and kinetic studies on the adsorption of humic acid onto chitosan- $\mathrm{H}_{2} \mathrm{SO}_{4}$ beads. Desalination 2011, 272, 293-300.

34. Rehman, R.; Manzoor, I.; Mitu, L. Isothermal study of congo red dye biosorptive removal from water by solanum tuberosum and pisum sativum peels in economical way Bull. Chem. Soc. Ethiop. 2018, 32, 213-223.

35. Krishna, Y.V.S.S.; Sandhya, G.; Babu, R.R. Removal of heavy metals $\mathrm{Pb}(\mathrm{II}), \mathrm{Cd}(\mathrm{II})$ and $\mathrm{Cu}(\mathrm{II})$ from waste waters using synthesized chromium doped nickel oxide nano particles. Bull. Chem. Soc. Ethiop. 2018, 32, 225-238.

36. Baccar, R.; Blánquez, P.; Bouzid, J.; Feki, M.; Attiya, H.; Sarrà, M. Modeling of adsorption isotherms and kinetics of a tannery dye onto an activated carbon prepared from an agricultural by-product. Fuel Process. Technol. 2013, 106, 408-415.

37. Singh, R.K.; Kumar, S.; Kumar, S.; Kumar, A. Development of parthenium based activated carbon and its utilization for adsorptive removal of $p$-cresol from aqueous solution. $J$. Hazard. Mater. 2008, 155, 523-535.

38. Salman, J.M.; Njoku, V.O.; Hameed, B.H. Bentazon and carbofuran adsorption onto date seed activated carbon: kinetics and equilibrium. Chem. Eng. J. 2011, 173, 361-368.

39. Memon, G.Z.; Bhanger, M.I.; Akhtar, M. The removal efficiency of chestnut shells for selected pesticides from aqueous solutions. J. Colloid Interface Sci. 2007, 315, 33-40.

40. Salman, J.M.; Hameed, B.H. Removal of insecticide carbofuran from aqueous solutions by banana stalks activated carbon. J. Hazard. Mater. 2010, 176, 814-819.

41. Salman, J.M.; Hameed, B.H. Adsorption of 2,4-dichlorophenoxyacetic acid and carbofuran pesticides onto granular activated carbon. Desalination 2010, 256, 129-135.

42. Weber, W.J.; Morris, J.C. Kinetics of adsorption on carbon from solution. J. Sanit. Eng. 1963, 89, 375-393.

43. Khaled, A.; El Nemr, A.; El-Sikaily, A.; Abdelwahab, O. Removal of Direct N Blue 106 from artificial textile dye effluent using activated carbon from orange peel: adsorption isotherm and kinetic studies. J. Hazard. Mater. 2009, 165, 100-110.

44. Agarry, S.E.; Owabor, C.N.; Ajani, A.O. Modified plantain peel as cellulose-based low-cost adsorbent for the removal of 2,6-dichlorophenol from aqueous solution: Adsorption isotherms, kinetic modelling and thermodynamic studies. Chem. Eng. Commun. 2013, 200, 1121-1147.

45. Hamad, B.K.; Ahmad, M.N.; Afidah, A.R. Removal of 4-chloro-2-methoxy phenol by adsorption from aqueous solution using oil palm shell carbon activated by $\mathrm{K}_{2} \mathrm{CO}_{3}$. J. Phys. Sci. 2011, 22, 41-58.

46. Li, Q.; Yue, Q.; Su, Y.; Gao, B.; Sun, H. Equilibrium, thermodynamics and process design to minimize adsorbent amount for the adsorption of acid dyes onto cationic polymer-loaded bentonite. Chem. Eng. J. 2010, 158, 489-497. 